\title{
$5-2013$
}

\section{Productivity in the Cognitive Overload Era}

George K. Thiruvathukal

Loyola University Chicago, gkt@cs.luc.edu

Follow this and additional works at: https://ecommons.luc.edu/cs_facpubs

Part of the Computer Sciences Commons, Curriculum and Instruction Commons, and the Higher Education Commons

\section{Recommended Citation}

G. K. Thiruvathukal, "Productivity in the Cognitive Overload Era," in Computing in Science \& Engineering, vol. 15, no. 3, pp. 4-5, May-June 2013. doi: 10.1109/MCSE.2013.65

This Article is brought to you for free and open access by the Faculty Publications and Other Works by Department at Loyola eCommons. It has been accepted for inclusion in Computer Science: Faculty Publications and Other Works by an authorized administrator of Loyola eCommons. For more information, please contact ecommons@luc.edu.

\section{(c) (1) $\$ \odot$}

This work is licensed under a Creative Commons Attribution-Noncommercial-No Derivative Works 3.0 License. Copyright @ 2013 George K. Thiruvathukal 


\title{
F R O M \\ THE EDITOR S
}

\section{Productivity in the Cognitive Overload Era}

\author{
By George K. Thiruvathukal
}

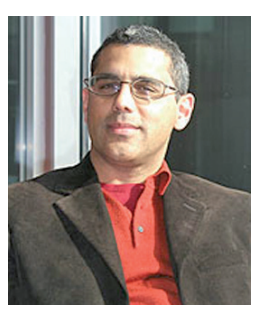

\section{ECENTLY, I'VE THOUGHT A GREAT DEAL ABOUT PRODUCTIVITY, BECAUSE \\ THE WORK OF COMPUTING PROFESSIONALS SEEMS NECESSARY (AGAIN)}

\author{
TO TAME THE WILD CREATURE THAT WE CREATED IN THE FIRST PLACE:
}

THE PERVASIVE INTERNET. MORE IMPORTANTLY, I WANT AND NEED TO BE

productive (but will defer the details of what I want to produce) with the hope of having a normal work schedule.

In this great Internet age, two tools were created: e-mail and the Web. Without a doubt, we're happy to have both of these tools. After all, our ability to communicate is the foundation that makes efficient collaboration possible. Somewhere along the way, though, something has gone terribly wrong. The mobile era (as an augmentation of the Internet) brought texting and what I can only term as a deluge of notifications. The end result has been that we spend the vast majority of our time being interrupted. Much like preemption in an operating system and oversubscribing pages of memory, this is paramount to a thrashing condition. Humans are capable of many things that will likely continue to give computers trouble (abstract thinking and problem solving), but as humans we're astonishingly poor at multitasking more than a handful of activities.

\section{Chunking and Workloads}

Miller's law, named after George A. Miller, is not a law in the scientific sense; this law introduced the $7+/-2$ (7 plus or minus 2) principle, which describes the limits of shortterm memory. Later work would go on to demonstrate that chunking (and how chunks are defined) can further limit the number 7 (in some cases to as low as 4). Without going into details, the work of Miller and his successors, which became known to the world in the 1950s (1956 for $7+/-2$ ), suggests that we're in serious trouble. Given the fine-grain chunking of e-mail, notifications, and texts, we're destined to be unproductive for the next decade unless a dramatic transformation takes place. In the fast-paced world of academic life, this is a problem that we should care about solving.

Luckily, we don't need to wait for space-age discoveries to bring some short-term improvements to this madness. Like many who entered academics, I was one of the folks who relished having complete control of my schedule and the flexibility that an academic life affords in terms of having time to think and be creative (for research and extracurricular activities). I keep scratching my head, because the last time I thought of an academic job this way was sometime in the late 1990s, when my Internet life was relatively distraction-free. It has become apparent that this life is becoming even more of a "full-time job" than it used to be, and much of it isn't dedicated to our core mission as academics.

Because of our increasingly hectic schedule, in 2011 Konstantin Läufer (my fellow colleague and a CiSE department editor), David Dennis (a historian at my university), and I started thinking about what creates so many distractions. Although much of our experience is specific to our university, I talk to a lot of folks outside of my university on a regular basis and sense that the experiences are nearly identical.

One key thing we discovered is that universities, similar to many companies, have IT departments that spend most of their time thinking about how to control the users and keep costs under control. So-called "standards" and "supported" solutions prevail and sometimes linger for decades. In the meantime, a parallel universe has been forming (in the cloud) that's finally the realization of Sun's concept of "the network is the computer," which as we all know led to the eventual creation of the net-centric Java programming language.

We discussed some of these findings in an article we wrote, called "Initial Experiences in Moving Key Academic Department Functions to Social Networking Sites," (see http://ecommons.luc.edu/cs_facpubs/36). In particular, we spoke about the need to move various aspects to the cloud at the risk of becoming obsolete: course management, research collaboration, and community engagement. Since writing this article, we've been doing it and finding that the end result is that we're spending less time fighting about university technology decisions and more time on engagement-not just of students but each other as faculty and research collaborators. In addition, some of the interruptions are getting under control, although notifications remain a challenge. 


\section{Control Issues and the Cloud}

And because we all know the world works in Internet time, the rug is being pulled out from underneath us anyway, with the proliferation of cloud-based solutions. Consider, as an example, course management software. Two known instances of this are Blackboard and an open source option, Sakai. This year, our university - among many others-decided it's time to move beyond Blackboard, although it had "served our interests well" (a euphemism for "its time had come and gone"). Although I was ambivalent about this software from the beginning, I knew that open source alternatives such as Moodle and Sakai were fraught with a number of support headaches, especially at scale, which played right into the traditional IT "support" mantra. Nevertheless, it wasn't long before a commercially supported solution, Sakai, became available that the university moved in this direction. It was, however, a classic case of too little too late, although without a doubt it's a viable solution for those who need basic course management functionality (I use it as my grade book). The fundamental problem I have with these supported solutions is that they're just that - supported - and require way too much human intervention (or supervision, to employ a term that we use to talk about algorithms in the computing world), which means that the users (faculty, graduate assistants, and students) aren't in control.

Meanwhile, in the parallel universe, many hosted and freely available solutions for hosting courses, especially the ones that are theoretically encroaching on our bread and butter-so-called massive open online courses (MOOCs) - are beginning to take the world by storm. This semester, I've been using Piazza (www.piazza. com) for most of the functions associated with my class. Piazza is great. You basically create your own course (as a professor) and then confirm that you're with the university through your .edu address. Next, you can add your graduate assistants and students to the course and assign roles to them. Then you upload your content. And voila, you're ready to go. The important part of this: no IT support is required. More importantly, there's no worrying about whether the software is going to be available.

Thus the cloud, while still not perfect, has higher uptime guarantees than anything we maintain on our own (at least during my period of evaluation). Students also seem to like it. We're able to do things such as group discussions - on any client, not just a desktop-based Web browser-with all major clients, including smartphones and tablets. o what's happening now is the beginning (or perhaps the middle) of something big. We're seeing the emergence of technologies (more of which are covered in the aforementioned article) that are focused more on the idea of we and less on me. By this, I mean that the technologies are fundamentally constructed for group interaction. In due time, this could help reduce the amount of e-mail we receive, where e-mails are pushed to mobile notifications; but the jury is still out, because notifications interrupt us. By having group abstractions from the beginning, however, it's possible that the crowd (as opposed to me) can react to the notifications, thereby taking some of the pressure off of me. The hope, however, is that these notifications are less critical than most direct messaging (e-mail and text), so they can be silenced using features such as Apple's Do Not Disturb option on mobile devices-especially outside of business hours when, dare I say it, we hope to have a life.

As always, I'm interested to hear your thoughts. Catch me on Google+ at http://gplus.to/gkt or e-mail me at gkt@ cisemagazine.org.

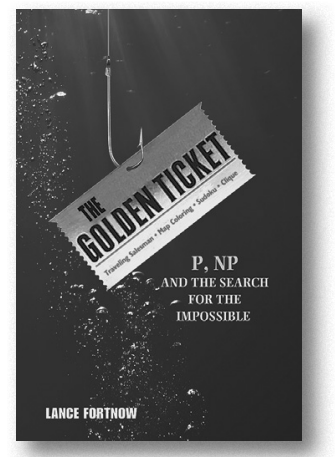

\section{The Golden Ticket}

P, NP, and the Search for the Impossible

Lance Fortnow

"You will love this book. It's completely accessible and captures the thrill, potential, and heartbreak of an edgy mathematical problem in terms that nonmathematicians will appreciate. After reading The Golden Ticket, I sort of hope P isn't NP after all."

—Vint Cerf, Google Vice President and Chief Internet Evangelist and one of the "Fathers of the Internet"

"Nobody explains the importance of the P-NP problem better than Fortnow."

-William J. Cook, author of In Pursuit of the Traveling Salesman

Cloth \$26.95 978-0-691-15649-1

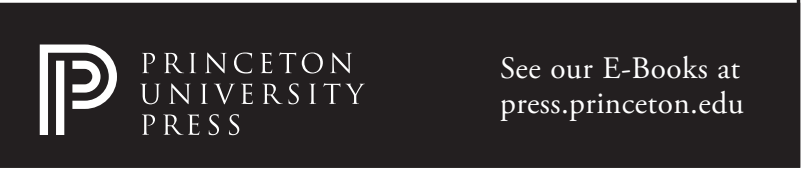

